\title{
QUALITY OF LIFE EVALUATION IN CELIAC PATIENTS FROM SOUTHERN BRAZIL
}

\author{
Amélia C CASTILHOS'1, Bárbara C GONÇALVES'1, Manoella MACEDO E SILVA', \\ Laura A LANZONI', Letícia R METZGER ${ }^{1}$, Lorete M S KOTZE ${ }^{2}$ and Renato M NISIHARA ${ }^{1}$
}

Received 20/1/2015

Accepted 17/3/2015

\begin{abstract}
Background - Restrictions imposed by the gluten-free diet generate large changes in the daily habits of the celiac patient, causing a negative impact on quality of life. Objetive - This study aimed to evaluate the quality of life of patients with celiac disease on a capital in Southern Brazil. Methods - Patients older than 18 years were included, with confirmed celiac disease for at least 60 days in the period from June to October 2013. A validated questionnaire, with specific questions to assess the patient's quality of life celiac was applied. A total score ranged from 20 to 100 points; the higher the score, worse quality of life. Results - A total of 103 questionnaires were evaluated, $96(93.2 \%)$ female, with average score 56.6 \pm 12.35 (28 to 88 points). The comparison between the questionnaire scores and family income was not significant $(P=0.139)$. Patients diagnosed less than 1 year have poorer quality of life than those with more than 10 years $(P=0.063)$. Patients older than 60 years had better quality of life compared with the younger ones $(P=0.04)$. Conclusion - There was no association between quality of life and factors such as family income, length of diet and age at diagnosis. Chronological age greater than 60 years has positively influenced the quality of life of celiac patients.
\end{abstract}

HEADINGS - Celiac disease. Quality of life. Gluten-free-diet.

\section{INTRODUTION}

Celiac disease $(\mathrm{CD})$ is characterized by a chronic inflammatory response in the intestine in response to ingestion of gluten present in the diet. It is a multifactorial disease, which leads to intestinal inflammation, loss of intestinal villi and, therefore, nutrient malabsorption, that results from the combination of genetic susceptibility, environmental exposure and immune response ${ }^{(5)}$. The classic form of the disease presents with gastrointestinal symptoms, such as bloating and chronic diarrhea, but atypical forms are frequent and range from extra-intestinal symptoms until asymptomatic forms ${ }^{(12,13)}$. CD primarily affects individuals with European descent and its development is strongly influenced by genetics. In Brazil, the South and Southeast regions have the highest prevalence, both for its strong European colonization and the greater availability of diagnostic tests.

An international multicenter study reported that the prevalence of CD worldwide is approximately $1 \%$, with high variation between countries. The prevalence is estimated to be increasing, although the disease is often not diagnosed ${ }^{(1)}$. To estimate the prevalence of $\mathrm{CD}$ in general population, blood donors have been investigated. In Brazil, there are currently studies of blood donors in Brasilia, Curitiba and Ribeirão Preto showing a variation in prevalence between 1: 681, 1 : 417 and 1: 214, respectively. These findings indicate that $\mathrm{CD}$ should not be considered a rare disease in the country ${ }^{(9,15)}$. Another finding in studies of epidemiology is that $\mathrm{CD}$ is most prevalent in women, with an estimated ratio of two women patients for each $\operatorname{man}^{(2,12,13)}$.

Early diagnosis and treatment are essential in preventing complications such as malnutrition, osteoporosis, infertility and cancer ${ }^{(16)}$. Serological tests with antiendomysium antibody and anti-tissue transglutaminase exhibit high sensitivity and specificity $(>90 \%)$ and are important in the screening of potential celiac patients ${ }^{(18)}$.

Currently, the only available treatment is a gluten-free diet (GFD) ${ }^{(4,17)}$, which, once established, stops clinical symptoms, combats nutritional deficiencies, and reduces the risk of developing other autoimmune diseases and malignancies associated with $\mathrm{CD}^{(21)}$. The restrictions imposed by the GFD generate large changes in the daily habits of the patient and their families and can be difficult to maintain throughout life ${ }^{(11,22)}$. Thus, there are studies that show an adequate response to therapy in over $30 \%$ of patients ${ }^{(4,14)}$. The difficulty of finding gluten-free

Departamento de Medicina, Universidade Positivo, Curitiba, PR; ${ }^{2}$ Serviço de Gastroenterologia, Pontifícia Universidade Católica do Paraná, Curitiba, PR, Brasil.

Correspondence: Renato Mitsunori Nisihara. Universidade Positivo, Departamento de Medicina. Rua Prof. Pedro Viriato Parigot de Souza, 530. Campo Comprido - CEP 81280-330 - Curitiba, PR, Brasil. Email: renatonisihara@up.com.br 
foods, the high cost and the inadvertent consumption of food containing the substance are factors that contribute to lower adherence to the $\operatorname{diet}^{(3)}$.

New treatments for $C D$ have been studied, which include the development of transgenic grain gluten free, blocking epithelial zonulin receptor, and vaccines that induce oral tolerance to gluten. These types of treatment are encouraging results in phase II and III studies and do not depend on patient compliance to the $\operatorname{diet}^{(3)}$.

$\mathrm{CD}$, like most chronic diseases, has a negative impact on the quality of life (QOL) of the patient, both for its clinical manifestations that are variable for each individual, and by food restriction that complicates, among other things, interpersonal relationships ${ }^{(8)}$.

The present study aimed to evaluate the QOL of patients with $C D$ on a capital in southern Brazil through validated questionnaire, comparing the results with clinical and epidemiological data.

\section{METHODS}

The study was observational analytic cross-sectional design and was approved by the Ethics Committee on human research of Positivo University.

Patients older than 18 years were included, with a confirmed diagnosis of $\mathrm{CD}$ for at least 60 days, attending meetings of the Association of Celiac from Paraná (ACELPAR) and signed an informed consent form (ICF). Individuals who did not meet these criteria were excluded.

The ACELPAR aims to inform about the $\mathrm{CD}$, providing support, recipes and meetings that are held monthly.

Two types of questionnaire were used in the period from June to October 2013. The first with clinical and epidemiological questions (chronological age, age at diagnosis, gender, ethnicity, nationality and family income) and the second entitled Celiac Disease - Quality of Life (CD-QOL) ${ }^{(7)}$, composed of 20 specific questions to assess the patient's QOL celiac, validated in English and translated into Portuguese by the authors of this study. Each question was rated from one to five, and the total score ranged from 20 to 100 points; the higher the score, the worse QOL.

\section{RESULTS}

Over 103 questionnaires were evaluated, 96 (93.2\%) patients were female and seven $(6.8 \%)$ were male. Because of the low number of men who responded to the questionnaire, its exclusion from the statistical analysis was required. Demographical data are shown in Table 1. All respondents reported being doers of GFD.

Among the 96 questionnaires analyzed, the average score was $56.63 \pm 12.35(95 \% \mathrm{CI}=53.1$ to 58.9 points), with a minimum value of 28 and a maximum of 88 points. Twenty-four patients $(25 \%)$ had higher scores on average and a standard deviation of 68 points; of these, eight $(8.3 \%)$ totaled more than 80 points, suggesting a worse QOL. Considering that $75 \%$ of patients accounted for less than 68 points, it was
TABLE 1. Demographic data of the patients studied $(\mathrm{n}=103)$

\begin{tabular}{lc}
\hline Age & $\mathrm{n}(\%)$ \\
Average $42.1 \pm 11.0$ & \\
$18-30$ years & $16(16.6 \%)$ \\
$31-45$ years & $48(50 \%)$ \\
$46-60$ years & $21(21.8 \%)$ \\
$>61$ years & $11(11.4 \%)$ \\
Ethnicity & \\
White & $89(92.7 \%)$ \\
Afrodescendant & $5(5.2 \%)$ \\
Yellow & $2(2 \%)$ \\
Family income & \\
Class A and B & $42(43.7 \%)$ \\
Class C, D and E & $33(34.4 \%)$ \\
Not answered & $21(21.9 \%)$ \\
\hline
\end{tabular}

inferred that the QOL assessed by the questionnaire used in the study was fairly well studied in CD.

The comparison between the CD-QOL scores and family income (Figure 1) lower and higher than five minimum wages was not statistically significant $(P=0.139)$ and less than five times and greater than ten times the minimum wage $(P=0.100)$.

On average, the time diagnosis was 5.1 years, ranging between 1 and 34 years. It is noteworthy that the time of diagnosis implies GFD time for most patients. When com-

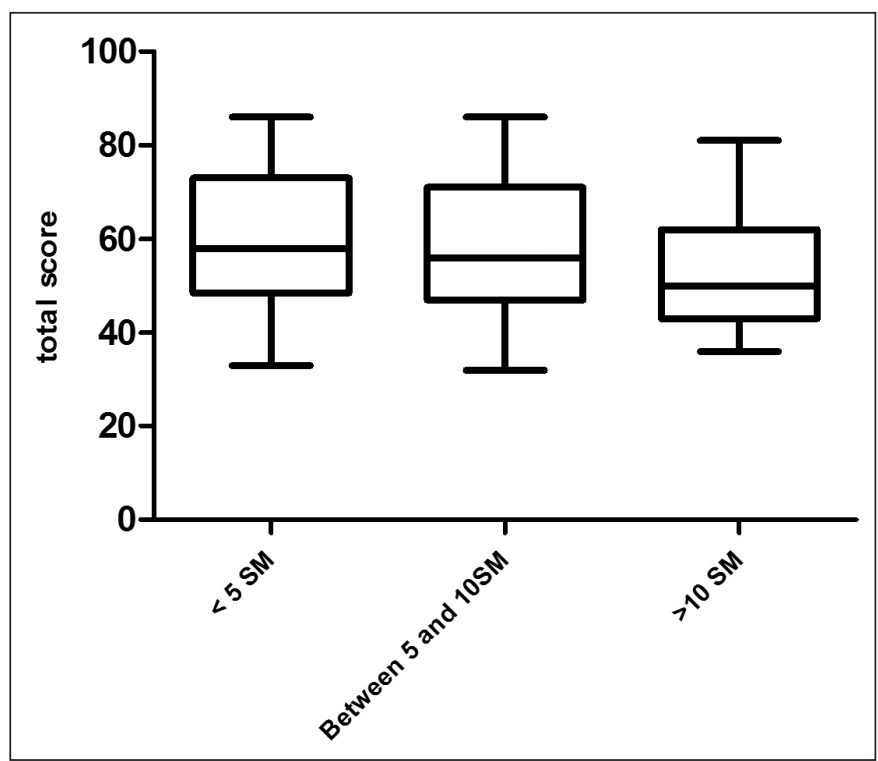

FIGURE 1. Scores obtained on Celiac Disease - Quality of Life and family income in celiac disease patients.

SM: minimum wage 
paring the CD-QOL score and the time to diagnosis of $\mathrm{CD}$ lower and higher than four years (Figure 2), no statistical difference $(P=0.28)$ was noted. Patients diagnosed less than 1 year were noted to have poorer QOL than those with more than 10 years of diagnosis, with no statistical significance but pointing trend $(P=0.063)$. The comparison between participants who obtained the lowest and highest CD-QOL score at the time of diagnosis also did not reach statistical significance $(P=0.74)$.

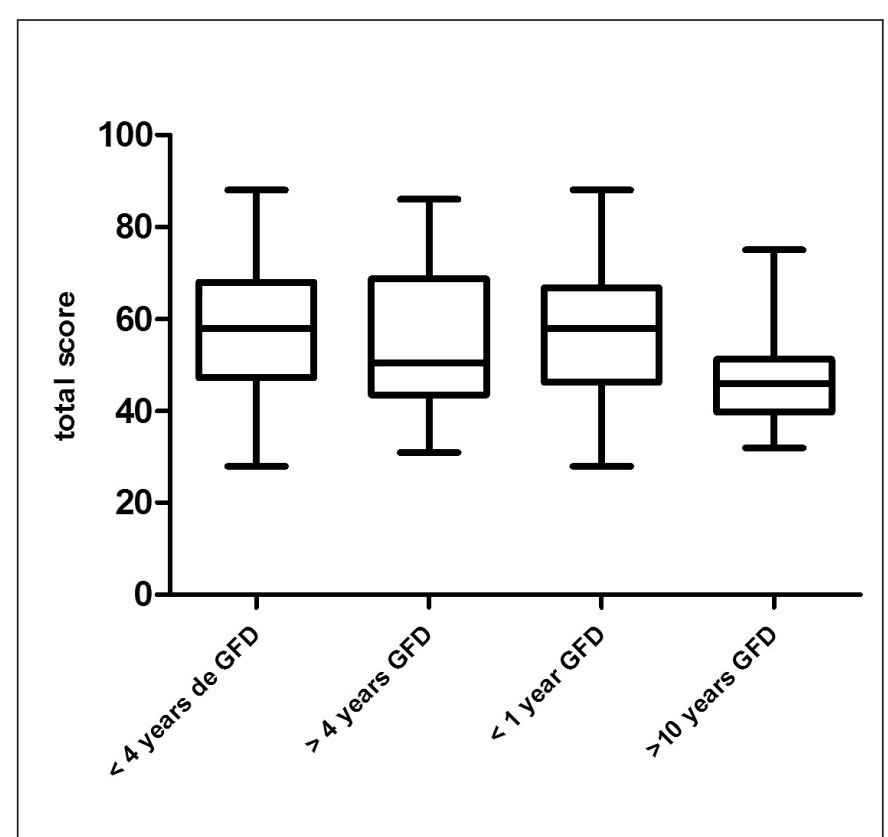

FIGURE 2. Scores obtained on Celiac Disease - Quality of Life and time of diagnosis of celiac disease with gluten free diet.

GFD: gluten-free diet.

The median age of patients at the time of study entry was 40 years, ranging between 20 and 78 years. Patients with more advanced age had better QOL compared with the younger ones. In dividing the subjects into age groups of 30 to 45 versus greater than 60 years, we obtained a $P=0.0199$. In the comparison between younger than 30 s and older than 60 s, a $P$ value of 0.0428 was found (Figure 3).

Three questions on the CD-QOL were selected for analysis. Of the five options of possible answers, we excluded "sometimes" and considered "often" and "always" as negative and "rarely" and "never" as positive responses. The first issue (number 10), that asked about the feeling of sadness because of $C D$, showed a positive response of $14 \%$ and a negative response of $57.95 \%$. The second (number 12), who questioned the lack of knowledge about the disease, presented a $21.5 \%$ positive responses and $50.47 \%$ negative ones. The third (number 19), who questioned the preoccupation with food, showed $18.7 \%$ positive responses and $57 \%$ negative.

Among people with worse QOL assessed using the questionnaire $(n=24)$, no particulars regarding the studied clinical and epidemiological parameters were observed.

\section{DISCUSSION}

QOL evaluate objective and subjective aspects of everyday life. It also evaluate how the needs and expectations of patients are affected by their condition. From this perspective, some authors investigated the impact of $\mathrm{CD}$, and also the GFD, on patients lives ${ }^{(4,22)}$. However, no studies on the topic were found in Brazil.

The proportion of $\mathrm{CD}$ between the genders is two women to one man ${ }^{(22)}$. However, in this study, it was necessary to remove the statistical analysis of the data provided by men because of their low adhesion to the research. This fact finds that the low participation of men in ACELPAR meetings, where the questionnaires were administered, and more broadly, their lowest interest in health care, when compared with women. Other authors reported similar findings ${ }^{(6,20)}$.

Importantly, the ethnic difference between Southern Brazil and other regions of the country was due to the strong European colonization present in the area of data collection. $\mathrm{CD}$ is a disease classically associated with white ethnicity and highlights the presence of celiac who declared having African (4.8\%) and Asian descent (2.9\%), showing a strong ethnic mix of Brazil, even in the South.

In 2011, Barrat et al. ${ }^{(4)}$ assessed the likelihood of developing anxiety and depression in patients with $\mathrm{CD}$. These authors showed that the celiac in the UK have a reduced QOL and are more likely to develop anxiety and depression compared with controls of the same age and gender. In disagreement with the results reported, the present study found that most patients did not have depressed mood.

In 2007, Häuser et al. ${ }^{(10)}$ reported that the correlation between the impact of CD and GFD in the QOL of patients

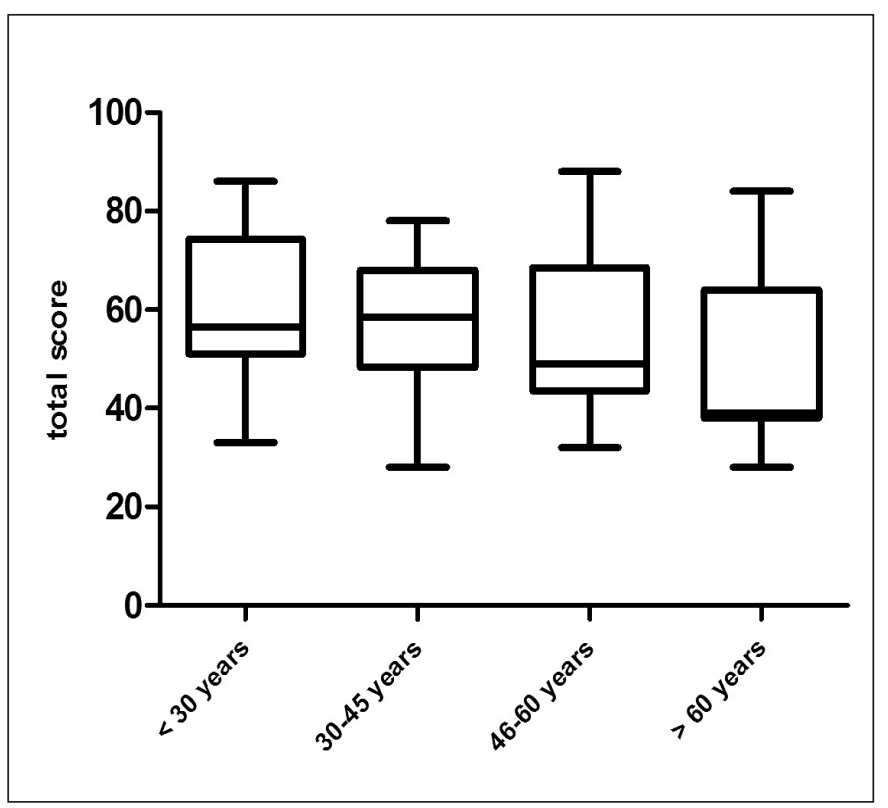

FIGURE 3. Scores obtained on Celiac Disease - Quality of Life and chronological age of the patient. 
is conflicting. American, Canadian and Swedish studies reported similar health-related findings between celiac and the general population with QOL; Italian, German, and Irish studies have shown a reduced QOL. Characteristics related to cultural habits and sociodemographic characteristics partly explain these differences between countries. On the other hand, the results of studies on the QOL of CD cannot be fully comparable because of the various instruments used to collect data with different scores and forms of analysis ${ }^{(10)}$. In this study, the average score of CD-QOL was 56 points, from 20 to 100 points, according to calculations; $75 \%$ of the respondents had values below 68 points, suggesting that the QOL of patients evaluated is slightly better than that found in the literature.

Zarkadas et al. ${ }^{(22)}$ demonstrated the important role of celiac organizations who offer emotional and social support and encourage adherence to the diet. Häuser et al. ${ }^{(19)}$ noted the dissatisfaction of patients in relation to the amount of information provided by the physicians and explained the importance of good physician-patient relationship, which also improves adherence. In the present study, the majority of patients were considered to be sufficiently informed about CD. It is possible that the support of ACELPAR and the medical care offered to patients assessed have influenced the results.

The perception that gluten-free products are generally more expensive than the others suggests that household income may interfere with the GFD. Barrat et al.$^{(4)}$ reported that patients with higher socioeconomic status and college education are more adherent to the GFD because they have more resources to do so. However, there is no evidence to show a clear correlation between these factors and better QOL in patients with CD. In the present study, no statistically significant association between family income and the CDQOL scores was observed. Additionally, other factors related to the GFD could influence the QOL of these patients. One of the questions this study asked about was the general and constant preoccupation with food, and again, only $18.7 \%$ of participants responded affirmatively. This result is surprising because it contradicts the idea that between celiac this is a constant concern.

Diagnosis of CD requires GFD for lifelong. Patients newly diagnosed (less than a year) were compared with those who had the diagnosis longer (over 4 years) and no significant influence was observed on QOL. On the other hand, when compared with celiac over ten years of diagnosis, it has been observed that patients that were longer diagnosed had better $(P=0.063)$. This result suggests that the limitations imposed by disease and GFD also influence the patients, regardless of the length of diet. However, it seems that over the years, there is a better adaptation to the restrictions imposed by the binomial disease-treatment.
Assessing the chronological age of the surveyed, better QOL of patients older than 60 years, when compared with other age groups, was found. It is possible that factors related to this phase of life lead that improved QOL among them stands out to the best adaptation to GFD, more meals taken at home and more time available for food preparation. Local features such as greater access to sources of food without gluten and in greater ability and experience in food preparation are a positive influence and improve adaptation to GFD.

Limitations encountered in the study stemmed from the fact that there is not a record of the number of celiac patients in Brazil, not allowing the calculation of the sample. Similar limitation has been reported by Zarkadas et al. ${ }^{(22)}$ in Canada. In addition, people who frequent celiac associations have greater interest and are better informed about the disease. They also, receive and exchange experiences on how to adapt to the GFD, and these factors can positively influence QOL. Moreover, questions of an intimate nature are not subject to this bias. We also lament the fact of not being able to make comparative analysis between the genders, due to the low number of male respondents to the questionnaire. It is noteworthy that celiac patients should receive a comprehensive treatment that addresses the psychosocial and not just the biological aspects so that the disease causes little influence on their QOL.

The present study showed that the QOL of patients interviewed in a capital of Southern Brazil is higher than expected. There was no association between QOL and factors such as family income, length of diet and age at diagnosis. CD patients surveyed felt well informed, showed no declining trend and showed no constant worry about their food. It is believed that these results are linked to the information and support received, reinforcing the importance of patients associations to better QOL for celiac. Finally, it was found that chronological age greater than 60 years has positively influenced the QOL of celiac patients.

\section{AKNOWLEDGMENT}

The authors appreciate the cooperation of all members of ACELPAR (Associação dos celíacos do Paraná; http:// www.fenacelbra.com.br/acelpar/institucional/), in particular the president Juliana Gomes Werneck.

\section{Authors' contributions}

Castilhos AC, Kotze LMS and Nisihara RM: conception and study design analysis and/or interpretation of data, final approval of manuscript, writing of the manuscript or review of its content. Gonçalves BC Lanzoni LA, Metzger LR and Silva MM: data collection, analysis and interpretation of data; approval of the final version of the manuscript. 
Castilhos AC, Gonçalves BC, Macedo e Silva M, Lanzoni LA, Metzger LR, Kotze LMS, Nisihara RM. Avaliação da qualidade de vida do paciente celíaco do Sul do Brasil. Arq Gastroenterol. 2015,52(3):171-5.

RESUMO - Contexto - Restrições impostas pela dieta isenta em glúten podem gerar grandes mudanças nos hábitos diários do paciente celíaco, causando um impacto negativo na sua qualidade de vida. Objetivo - Este estudo teve como objetivo avaliar a qualidade de vida de pacientes com doença celíaca, em uma capital do Sul do Brasil. Métodos - Pacientes maiores de 18 anos foram incluídos, com doença celíaca confirmada há mais de 60 dias, no período de junho a outubro de 2013. Um questionário validado, com perguntas específicas para avaliar a qualidade de vida do paciente celíaco foi aplicado. A pontuação total nesse questionário varia entre 20 a 100 pontos; quanto maior a pontuação, pior a qualidade de vida. Resultados - No total 103 questionários foram avaliados, sendo $96(93,2 \%)$ do sexo feminino, com pontuação média de 56,6 112,35 (28-88 pontos). A comparação entre os escores do questionário e renda familiar não foi significativa $(P=0,139)$. Pacientes diagnosticados há menos de 1 ano, apresentam pior qualidade de vida do que aqueles com mais de 10 anos $(P=0,063)$. Pacientes com mais de 60 anos apresentaram melhor qualidade de vida em comparação com os mais jovens $(P=0,04)$. Conclusão - Não houve associação entre a qualidade de vida e fatores como renda familiar, tempo de dieta e idade no momento do diagnóstico. A idade cronológica superior a 60 anos influenciou positivamente a qualidade de vida de pacientes celíacos.

DESCRITORES - Doença celíaca. Qualidade de vida. Dieta livre de glúten.

\section{REFERENCES}

1. Alencar ML, Ortiz-Agostinho CL, NIshitokukado I, Damião AO, Abrantes-Lemos CP, Leite AZ, et al. Prevalence of celiac disease among blood donors in São Paulo - the most populated city in Brazil. Clinics. 2012;67(9):1013-8.

2. Bai JC, Fried M, Corazza GR, Schuppan D, Farthing M, Catassi C, et al. World Gastroenterology Organisation global guidelines on celiac disease. J Clin Gastroenterol. 2013;47(2):121-6.

3. Bakshi A., Stephen S, Borum ML, Doman DB. Emerging therapeutic options for celiac disease: potential alternatives to a gluten-free diet. Gastroenterol and Hepatol. 2012;8(9):582-8.

4. Barratt SM, Leeds JS, Sanders DS. Quality of life in celiac disease is determined by perceived degree of difficulty adhering to a gluten-free diet, not the level of dietary adherence ultimately achieved. J Gastrointestin Liver Dis. 2011;20(3):241-5.

5. Bertolazza S, Lanzarotto F, Zanini B, Ricci C, Villanacci V, Lanzini A.. Bio-physical characteristics of gastrointestinal mucosa of celiac patients: comparison with control subjects and effect of gluten free diet. BMC Gastronterol. 2011;11:119.

6. Couto MT, Gomes R. Homens, saúde e políticas públicas: a equidade de gênero em questão. Ciência \& Saúde Coletiva. 2012;17(10):2569-78.

7. Dorn SD, Hernandez L, Minaya MT, Morris CB, Hu Y, Leserman J, et al. The development and validation of a new coeliac disease quality of life surgey (CDQOL). Aliment Pharmacol Ther. 2010;31(6):666-75.

8. Dorn SD, Hernandez L, Minaya MT, Morris CB, Hu Y, Lewis S, et al. Psychosocial factors are more important than disease activity in determining gastrointestinal symptoms and health status in adults at a celiac disease referral center. Dig Dis Sci. 2010;55(11):3154-63.

9. Gandolfi L, Pratesi R, Cordoba JC, Tauil PL, Gasparin M, Catassi C. Prevalence of celiac disease among blood donors in Brazil. Am J Gastroenterol. 2000;95:689-92.

10. Häuser W, Stallmach A, Caspary WF, Stein J. Predictors of reduced health-related quality of life in adults with coeliac disease. Alimentary Pharmacology \& Therapeutics. 2007;25(5):569-78.
11. Hees NJM Van, Does W Van Der, Giltay EJ. Coeliac disease, diet adherence and depressive symptoms. J Psychosomatic Res. 2013;74(2):155-60.

12. Kotze LMS. Celiac disease in Brazilian patients: associations, complications and causes of death. Forty years of clinical experience. Arq Gastroenterol. 2009;46(4):261-9.

13. Kotze LMS. Distúrbios entéricos da absorção. In: DANI R. Gastroenterologia Essencial. 3. ed. Rio de Janeiro: Guanabara Koogan, p. 237-250, 2009.

14. Leffler DA, George JBE, Dennis M, Cook EF, Schuppan D, Kelly CP. A prospective comparative study of five measures of gluten-free diet adherence in adults with celiac disease. Aliment Pharmacol Ther. 2007;26(9):1227-35.

15. Melo SB; Fernandes MI; Peres LC. Prevalence and demographic characteristics of celiac disease among blood donors in Ribeirao Preto, Sao Paulo State, Brazil Dig Dis Sci. 2006;51(5):1020-5.

16. Nobre AR, Silve T, Cabral JEP. Doença celíaca revisitada. J Port Gastenterol, 2007:14:184-93.

17. Nordyke K, Norström F, Lindholm L, Stenlund H, Rosén A, Ivarsson A. Health-related quality of life in adolescents with screening-detected celiac disease, before and one year after diagnosis and initiation of gluten-free diet, a prospective nested case-referent study. BMC Public Health. 2013;13:142-9.

18. Pereira MA, Ortiz-Agostinho CL, Nishitokukado I, Sato MN, Damião AO, Alencar ML, et al Prevalence of celiac disease in an urban area of Brazil with predominantly European ancestry. World J Gastroenterol. 2006;12(40):6546-50.

19. Sollid LM, Jabri B. Triggers and drivers of autoimmunity: lessons from coeliac disease. Nature Publishing Group. 2013;13(4):294-302.

20. Travassos C, Viacava F, Pinheiro R, Brito A. Utilização dos serviços de saúde no Brasil: gênero, características familiares e condição social. Rev Pan Saúde Pub. 2002;11:5-6.

21. Tursi A, Elisei W, Giorgetti GM, Brandimarte G, Aiello F. Complications in celiac disease under gluten-free diet. Dig Dis Sci. 2009;54(10):2175-82.

22. Zarkadas M, Dubois S, Maclsaac K, Cantin I, Rashid M, Roberts KC, et al. Living with coeliac disease and a gluten-free diet: a Canadian perspective. J Hum Nutr Diet. 2012. 26(1):10-23. 